\title{
Retraction Note to: Environmental impact of plantations in and around the petroleum refinery: a case study
}

\section{Padma S. Rao • Vasant A. Mhaisalkar •}

\section{A. Shrivastava $\cdot$ Animesh Kumar • \\ T. Chakrabarti $\cdot$ S. Devotta}

Published online: 10 December 2018

(C) Springer Nature Switzerland AG 2018

\section{Retraction Note to: Environ Monit Assess (2010) 168:55-61 \\ https://doi.org/10.1007/s10661- 009-1091-6}

This article [1] has been retracted at the request of the Editor-in-Chief. Significant sections of the article show a similarity with the author's own article published previously [2]. All the authors agree with the retraction.

\section{References}

1. Rao, P.S., Mhaisalkar, V.A., Shrivastava, A. et al. Environ Monit Assess (2010) 168: 55. https://doi.org/10.1007 /s10661-009-1091-6
2. Rao, P.S., Gavane, A.G., Ankam, S.S. et al. Ecological Engineering (2004) 23(2):77. https://doi.org/10.1016/j. ecoleng.2004.06.013

Publisher's Note Springer Nature remains neutral with regard to jurisdictional claims in published maps and institutional affiliations.

The online version of the original article can be found at https://doi.org/10.1007/s10661-009-1091-6

P. S. Rao $(\bowtie) \cdot$ A. Shrivastava

Kolkata Zonal Laboratory, NEERI KoZL,

Kolkata 700107, India

e-mail:ps_rao@neeri.res.in

V. A. Mhaisalkar

Environmental Engineering Division, VNIT,

Nagpur, India

A. Kumar - T. Chakrabarti · S. Devotta

NEERI, Nagpur 440020, India 